\title{
Strategi Penguatan Organisasi Pelayanan Sosial Berbasis Keagamaan
}

Fauzik Lendriyono*

lendriyono@gmail.com

\begin{abstract}
Abstrak
Gejala sekularisasi organisasi pelayanan sosial semakin masif. Sekularisasi ini disebabkan karena masyarakat semakin rasional pada realitas sosial yang menuntut kualitas pelayanan sosial lebih baik. Masyarakat yang rasional adalah masyarakat yang mampu mengorganisir dan melakukan peran serta tindakan atas dasar pertimbangan logis atas realitas. Hadirnya organisasi menjadi cirri masyarakat rasional. Organisasi adalah bentukan sosial yang berisi kesepakatan gagasan pemikiran, nilai, ideologi dan tujuan. Ketika agama menjadi bagian di dalamnya, maka organisasi menjadi lebih kuat dengan tatanan nilai dan aturan-aturan yang selalu merujuk pada nilai agama sebagai dasar keyakinannya. Keyakinan pada nilai agama menjadi spirit organisasi untuk merancang dan merealisasikan tujuannya. Maka organisasi yang berbasis keagamaan memiliki sensifitas dan orientasi untuk kesejahteraan yang lebih baik. Kesejahteraan tidak hanya bagi obyek, tetapi juga bagi subyek organisasi. Tesis Weber bahwa semakin menguatnya organisasi atau lembaga formal di masyarakat justru akan mempersempit ruang-ruang keagamaan, ternyata tidaklah demikian. Justru dengan hadirnya agama dalam organisasi, maka jangkauan organisasi semakin luas, memasuki sel-sel organisasi secara lebih dalam dan manusiawi.
\end{abstract}

Kata kunci: Keagamaan, organisasi, strategi

\begin{abstract}
Symptoms of secularization of social service organizations are increasingly masiv. This secularization is caused by increasingly rational society in social reality that demands better quality of social services. A rational society is a society capable of organizing and performing action based on logical reasoning of reality. The presence of the organization became the cirri of rational society. Organization is a social form that contains agreement of ideas of thought, value, ideology and purpose. When religion becomes part of it, the organization becomes stronger with the order of values and rules that always refer to the value of religion as the basis of its belief. Confidence in the value of religion becomes the spirit of the organization to design and realize its objectives. Hence religious-based organizations have sensitivity and orientation for better welfare. Welfare is not only for the object, but also for the subject of the organization. Weber's thesis that the strengthening of formal organizations or institutions in society will actually narrow the religious spaces, it is not so. Precisely with the presence of religion within the organization, the scope of the organization increasingly widespread, entering the cells of the organization more deeply and humanely.
\end{abstract}

Keywords: organization, religion, strategy

\section{Pendahuluan}

Peran agama sebagai ajaran yang menyampaikan nilai-nilai keyakinan tentang kepercayaan kepada Tuhan Yang Maha Esa, tampaknya mulai bergeser

\footnotetext{
* Korespondensi: Prodi. Ilmu Kesejahteraan Sosial. GKB I Lt. 6. Fakultas Ilmu Sosial dan Ilmu Politik. Universitas Muhammadiyah Malang, Jl. Raya Tlogomas no. 246 Malang, telp. 0341-464318, Email: lendriyono@gmail.com
} 
menjadi semacam 'komoditas' di dalam aktifitas sebuah organisasi keagamaan. Komoditas dalam konteks ini diartikan sebagai peran sosial organisasi dengan kepentingan ekonomi yang didasarkan pada nilai ajaran agama. Komoditas ini yang kemudian dianggap oleh sebagian kalangan, dapat mempersempit ruang gerak agama sebagai penebar nilai-nilai kebaikan semacam kedermawanan, amal, kemanusiaan, solidaritas dan sejenis lainnya. Hadirnya agama (Islam) dalam peran sosial organisasi sebenarnya mengajarkan profesionalitas, terlebih jika organisasi tersebut bergerak pada pengolahan dana umat seperti zakat, infaq, shodaqoh dan lainnya.

Merujuk pada tesis Weber tentang rasionalisasi, maka setidaknya pemikiran tersebut menunjukkan bahwa semakin menguatnya organisasi atau lembaga formal di masyarakat, justru akan mempersempit ruang-ruang keagamaan yang ada dan akan semakin menguatkkan gejala sekulerisasi. Tesis Weber ini didasarkan pada asumsi bahwa peran agama yang kuat dalam ranah sosial, ekonomi dan politik dimasa lalu akan tergeser oleh semakin besarnya peran-peran lembaga formal dan semakin menguatnya birokratisasi di dalam struktur sosial. Meski demikian dalam tesisnya yang lain, Weber juga berpandangan bahwa berdasarkan studinya terhadap varian Calvinis masyarakat Kristen Eropa, konsep-konsep dasar keagamaan seperti kesalehan (ascetism) dan keselamatan berimplikasi pada perilaku ekonomi (Latief, 2013:174-175). Jadi semakin jelas bahwa hadirnya organisasiorganisasi yang membawa nilai-nilai ajaran agama dalam aktifitasnya, akan disertai dengan munculnya perilaku-perilaku ekonomi untuk menopang keberlanjutan organisasi itu sendiri.

Human Services Organization (HSO) adalah organisasi yang berfokus pada penyediaan pelayanan bagi manusia. Organisasi ini membawa misi sosial untuk memberikan pelayanan kepada masyarakat atas dasar nilai-nilai kemanusiaan, solidaritas, kedermawanan dan kebersamaan yang tabu berbicara keuntungan materi. Sebagai organisasi pelayanan, di dalam HSO juga ada praktik-praktik ekonomi yang tentunya bukan sebagai bagian utama dalam aktifitas organisasi dan bukan menjadi prioritas bagi HSO. Bahwa ada kepentingan ekonomi dalam HSO, hal itu bukanlah sebuah kesalahan, namun perlu diluruskan bahwa organisasi pelayanan sosial dengan basis keagamaan sekalipun, juga berhak menjaga kebeberlanjutan organisasinya dengan kekuatan ekonomi. 
Organisasi pelayanan sosial dengan basis agama adalah organisasi yang menjalankan aktifitas organisasinya didasarkan pada nilai-nilai ajaran agama atau disebut sebagai Faith Base Oeganization (FBO). sama halnya dengan HSO, FBO meskipun berdasar pada nilai ajaran agama, dalam aktifitas organisasinya juga terdapat praktik-praktik ekonomi yang dijadikan sebagai penopang keberlanjutan organisasi.

Dua organisasi besar selain sebagai penyedia pelayanan sosial juga berbasis pada ajaran agama adalah Muhammadiyah dan Nahdlatul Ulama. Keduanya sudah dikenal masyarakat dengan peran-peran sosialnya melalui berbagai program kemasyarakatannya. Bukti bahwa kedua ormas keagamaan ini mampu berperan sosial adalah eksistensinya yang sampai sekarang bertambah kuat berpengaruh pada sector ekonomi dan politik bangsa. Kedua ormas keagamaan ini juga memiliki strategi berbasis struktur sosial, kultur dan religious yang didukungan penuh oleh masyarakat.

\section{Memahami Organisasi sebagai Konstruksi Sosial}

Dalam pemahaman Teori Konstruksi Sosial, organisasi dapat dimaknai sebagai bentukan sosial. Artinya bahwa organisasi itu dibentuk dari idea atau gagasangagasan individu atau kelompok dalam suatu komunitas. Sebagai bentukan sosial, organisasi memiliki sejarah pemikiran tertentu tentang alasan-alasan atau dasar-dasar mengapa organisasi tersebut diadakan.

Sebelum membahas tentang organisasi sebagai bentukan (konstruksi) sosial, terlebih dahulu dipaparkan ulasan singkat tentang Teori Konstruksi Sosial dari Berger dan Luckmann (1966). Teori Konstruksi Sosial ini menjadi pusat pengembangan Teori Pranata (institutional theory) (Meyer dan Rowan, 1977; Zucker, 1977) dan banyak digunakan dalam ilmu organisasi (Barley dan Tolbert, 1997). Teori ini juga memandang kalau ada konstruksi-konstruksi sosial pada tingkat makro dan konstruksi sosial ini membentuk interaksi sosial pada tingkat mikro (Holt dan Sandberg, 2011:228). Sebagai contoh, pranata-pranata internasional, menentukan bagaimana politik domestik berkembang (Tienhaara, 2008:83; Moravcsik, 1997:539).

Gagasan pokok (main idea) Teori Konstruksi Sosial Berger dan Luckmann ini adalah bahwa manusia itu pada hakekatnya adalah memproduksi dirinya sendiri. Tidak ada tempat bagi individu untuk mengurung diri. Dalam 
melakukan produksi diri, individu selalu memerlukan suatu perkongsian sosial (social entreprise). Mereka secara bersama-sama menciptakan lingkungan manusia dengan segala bentuk sosio-budaya dan psikologisnya. Lebih lanjut, Berger menyatakan adalah tidak mungkin manusia mengembangkan dirinya sebagai manusia dalam keterisolasian melainkan harus berada dalam sebuah struktur, juga tidak mungkin seseorang dalam keterisolasian sebagai agensi yang memproduksi sebuah lingkungan kemanusiaan (Lemert, 1999: 285). Berger meyakini bahwa hubungan antara struktur dan agensi sebagai sebuah dialektika. Masyarakat membentuk individu-individu, demikian pula sebaliknya individu-individu membentuk masyarakat. Bentukan ini terjadi secara timbal balik berbentuk ikal dalam putaran terus menerus (a continous loop).

Kelebihan dari teori Berger dan Luckmann ini adalah penjelasan tentang bagaimana proses konstruksi sosial tersebut terjadi. Proses konstruksi sosial terjadi lewat sebuah siklus dari eksternalisasi, objektivikasi, dan internalisasi. Eksternalisasi merupakan ekspresi diri manusia ke dunia luar. Eksternalisasi menurut Berger adalah usaha pencurahan atau ekspresi diri manusia ke dalam dunianya, baik dalam kegiatan fisik maupun psikis. Ini sudah menjadi sifat dasar manusia bahwa ia akan selalu mengaktualisasikan diri dimanapun ia berada. Manusia tidak dapat dipahami sebagai ketertutupan yang lepas dari dunia luarnya. Manusia berusaha untuk menemukan dirinya melalui sebuah proses membangun dunia sosialnya yang merupakan bagian esensial dari kehidupan manusia. Dengan kata lain, eksternalisasi adalah upaya untuk menciptakan struktur yang stabil yang diperlukan untuk bertahan hidup. Sementara struktur itu sendiri merupakan sebuah produksi bersama (collective production) yang terjadi dalam kurun waktu yang sangat lama.

Objektivikasi merupakan hasil yang dicapai dari kegiatan eksternalisasi, yakni berupa realitas objektif yang terpisah dengan diri manusia tersebut. Objektivasi digambarkan oleh Berger sebagai penciptaan berbagai lembaga, bahasa, benda, peralatan, ilmu pengetahuan, kesenian dalam aktifitas struktur. Semua struktur itu memiliki aturan yang harus ditaati. Agar penciptaan itu menjadi obyektif maka harus ada aturan yang dibuat bersama. Struktur dimana manusia itu hidup akan memberi arah, peranan dan makna dalam sebuah totalitas. Dengan adanya struktur akan memberi kepastian tentang berbagai tindakan dan kemungkinan tindakan, peranan, 
identitas dan makna. Intinya bahwa obyektivasi adalah pada saat mana sebuah totalitas pemaknaan sedang diproduksi. Jadi obyektivasi merupakan tahap selanjutnya, dimana para aktor sosial secara simultan melakukan eksternalisasi atau melakukan tindakan sosial yang pada gilirannya membentuk sebuah realitas obyektif. Dalam perspektif fenomenologi, realitas obyektif yang dimaksud dianggap tidak akan pernah ada yang ada adalah inter subyektif.

Internalisasi adalah penyerapan kembali realitas tersebut ke dalam diri manusia masuk ke kesadaran sehingga membentuk dirinya sendiri (Muslich, 2008:151). Internalisasi bagi Berger (Lemert, 1999) kurang lebih sama pemahamannya dengan sosialisasi. Dalam internalisasi, peran (role) dan identitas (identity) sangat penting. Dengan peran dan identitas tertentu, anggota-anggota dari suatu struktur melakukan internalisasi. Masing-masing orang memiliki peran dalam struktur. Memainkan sebuah peran berarti menjadi sebuah pribadi (be that person). Kesadaran individual akan diri dan dunianya akan terbentuk sesuai dengan peranannya. Struktur obyektif akan membuat seseorang tidak hanya sekedar memainkan peranan (play a role) melainkan juga 'menjadi'. Misalnya dalam internalisasi mengenai nilai-nilai dalam penyelenggaraan organisasi pelayanan, 'menjadi' pengurus adalah proses menjadi, sepanjang menjadi pengurus tersebut didefinisikan oleh struktur. Para pengurus itu akan menginterpretasikan seluruh kehidupan, diri dan dunia sosialnya menurut identitas yang diberikan oleh struktur organisasi tersebut.

Deskripsi di atas dapat dipandang sebagai bentuk konstruksi sosial. Sebagai konstruksi sosial, penyelenggaraan sebuah organisasi memiliki aspek masalah dalam kebertahanan hidup, yakni; aspek eksternalisasi, aspek objektivikasi, dan aspek internalisasi. Jika penyelenggaraan organisasi merupakan bentukan dari nilai-nilai agama, maka aspek-aspek konstruksi sosialnya dapat dilihat dari dua perspektif yaitu perspektif sekuler dan perspektif religius. Kedua perspektif ini, dalam level objektivikasi, mencakup perspektif Human Service Organization (HSO) dan perspektif Faith Based Organization (FBO).

\section{Organisasi Pelayanan Manusia (Human Service Organization/HSO)}

Sebagai sebuah organisasi kesejahteraan umum, kinerja HSO dinilai dari keberlanjutan dan kualitas pelayanan pada mereka yang membutuhkan pelayanan 
(Barak, Nissly, dan Levin, 2001: 627). HSO dijelaskan sebagai sebuah organisasi yang berkontribusi dalam pemenuhan kebutuhan dan tujuan konsumen serta berkontribusi juga pada kesejahteraan sosial secara keseluruhan (Jones and May, 1997:84). Setidaknya ada dua teori yang berusaha menjelaskan HSO, yaitu Teori SPACE dan Teori Kontingensi.

Teori SPACE (Strategic Position and Action Evaluation) yang dikembangkan oleh Rowe, Mason, dan Dickel (dalam Steiss, 2003:75) menyatakan kalau sebuah organisasi dipengaruhi oleh empat dimensi, dua diantaranya merupakan dimensi internal, sementara dua lainnya adalah dimensi eksternal. Dimensi internal dari organisasi dalam Teori SPACE mencakup kekuatan keuangan dan keunggulan bersaing. Adanya dimensi kekuatan keuangan pada HSO, membuat HSO seolah sebagai organisasi swasta yang berorientasi komersial. Namun, perlu diperhatikan bahwa kalau HSO membutuhkan uang karena bertujuan untuk dapat bekerja efektif. Dimensi kekuatan keuangan dalam HSO, berbeda dengan dimensi kekuatan keuangan dalam perusahaan komersial.

Dalam konteks HSO, dimensi keuangan ini mencakup elastisitas pendapatan dari sumbangan donatur, pemerintah, atau yayasan, elastisitas pengeluaran, posisi aliran kas organisasi, likuiditas dan ROI (Return on Investment) dan jumlah modal kerja (Steiss, 2003:75). HSO dengan pendapatan dan pengeluaran yang teratur dan seimbang, aliran kas yang baik, memiliki likuiditas dan ROI yang baik, serta memiliki modal kerja tinggi akan mampu menyokong kegiatannya dengan sumber dana yang cukup, sehingga kinerja dapat terus optimal.

Dimensi internal kedua adalah keunggulan bersaing. HSO juga bersaing sebagaimana halnya organisasi lain. Hal ini terutama terkait dengan masalah rekruitmen. Untuk mendapatkan SDM yang bermutu, HSO harus bersaing dengan banyak organisasi lain yang menawarkan hal-hal yang tidak dimiliki HSO, misalnya penghasilan dan karir. HSO harus memberikan sesuatu yang dinilai mampu melebihi hal-hal tersebut bagi calon rekrut sehingga mereka tertarik untuk memilih bekerja dalam HSO daripada organisasi non-HSO. Menurut Steiss (2003:75), dimensi keunggulan bersaing ini untuk konteks organisasi pelayanan umum seperti HSO, mencakup tingkat kepuasan konstituen, penggunaan dan pengetahuan teknologis, dan mutu pelayanan. Karenanya, HSO dengan konstituen yang puas, memiliki 
pengetahuan yang baik dan mampu menggunakan pengetahuan tersebut secara efektif dan efisien, serta memiliki mutu pelayanan yang baik, adalah HSO yang memiliki keunggulan bersaing.

Dimensi eksternal yang mempengaruhi organisasi mencakup stabilitas lingkungan dan kekuatan industri. Stabilitas lingkungan merupakan dimensi umum yang mempengaruhi semua jenis organisasi. Ia mencakup tingkat inflasi, dampak kebijakan, elastisitas harga, perubahan teknologi, dan tekanan bersaing (Steiss, 2003:75). Ketika tingkat inflasi rendah, harga barang relatif stabil dan organisasi dapat bekerja dengan perencanaan keuangan yang ada. Hal ini juga bertautan dengan elastisitas harga. Jika harga terlalu elastis, maka sulit bagi organisasi melakukan perencanaan keuangan. Begitu pula, jika kebijakan yang mengatur tidak terlalu cepat berganti, organisasi memiliki cukup waktu untuk mengimplementasikan kebijakan dan melihat hasil jangka panjang positif yang diharapkan dari kebijakan tersebut. Jika kebijakan berubah sebelum dampak jangka panjang teramati, dampak tersebut dapat lenyap, apalagi jika kebijakan baru tergolong radikal dalam mereformasi kebijakan lama.

Perubahan teknologi menuntut organisasi menyesuaikan diri dengan teknologi yang ada. Teknologi yang terlalu cepat berubah membuat organisasi kesulitan dalam penyesuaian diri terutama ketika berhubungan dengan persaingan yang tinggi. Sebagai contoh, jika HSO dan perusahaan swasta bersaing untuk memperoleh SDM berkualitas dengan memberikan lowongan, maka teknologi informasi menjadi faktor penting. SDM yang awalnya ingin menjadi bagian dari SDM HSO, karena sulit memperoleh informasi tentang lowongan HSO, pada akhirnya dapat tertarik oleh lowongan yang diberikan perusahaan swasta, karena perusahaan terus melakukan publikasi lowongan pada berbagai media.

Walau begitu, lingkungan yang terlalu stabil juga tidak baik bagi organisasi. Ketika lingkungan terlalu statis, ia dapat membawa HSO pada kondisi obsolesens dan senesens (Baum dan Amburgey, 2000:5). Obsolesens adalah kondisi dimana sumberdaya akhirnya habis dan organisasi kehilangan energi. Senesens adalah kondisi dimana konflik internal menjadi menumpuk dan pada akhirnya menghabiskan kinerja organisasi dari dalam. Kedua hal ini terjadi karena perubahan lingkungan dibutuhkan agar organisasi mampu mengganti jenis sumberdaya yang mulai habis. Begitu juga, 
perubahan lingkungan dibutuhkan agar konflik internal memperoleh resolusi atau hilang begitu saja karena ditutupi oleh konflik baru (Andrews et al, 2012:23).

Faktor eksternal kedua adalah kekuatan industri. Kekuatan suatu industri dalam masyarakat ditandai dengan pentingnya industri tersebut bagi masyarakat tersebut. Sebagai contoh, industri minyak di negara kaya minyak, akan memiliki kekuatan besar ketimbang industri pakaian, misalnya. Ketika faktor ini dibawa pada konteks HSO, pertanyaannya menjadi bagaimana status HSO dalam lingkungan tempat ia seharusnya berfungsi (Steiss, 2003:76).

Teori Kontingensi dari Dess dan Beard (1984 dalam Andrews et al, 2012:18) tidak membagi dalam dimensi eksternal dan internal saja, namun memberikan adanya dimensi perantara, yaitu hubungan antara organisasi terhadap klien. Tiga dimensi Teori Kontingensi antara lain (Andrews et al, 2012): 1) Munifisensi (kapasitas sumberdaya). Munifisensi merupakan dimensi internal organisasi yang mampu memperkuat pengaruh isi, rumusan, dan implementasi kebijakan yang diambil oleh HSO untuk mengatur organisasinya (Andrews et al, 2012:15). Munifisensi yang rendah berakibat pada buruknya kinerja HSO (Gordon dan Monastiriotis, 2006; Hall dan Leeson, 2010; Gutierrez-Romero, Haubrich, dan McLean, 2008). 2) Kompleksitas (homogenitas - heterogenitas klien, konsentrasi dispersi). Kompleksitas yang tinggi berakibat pada buruknya kinerja HSO (Hall dan Leeson, 2010; Gutierrez-Romero et al, 2008). Walau begitu, hal ini bersifat ambivalen. Jika HSO berkinerja baik, yang tercermin pada banyaknya program layanan sosial yang dikeluarkan, kompleksitas dan ukuran HSO akan bertambah (Anderson, Orr, dan Silverman, 2000 dalam Scott, 2003:29). Karenanya, HSO yang berkembang berisiko mengalami kompleksitas yang semakin besar. 3) Dinamisme (stabilitas-ketidakstabilan lingkungan, turbulensi). Dinamisme dalam teori kontingensi sejalan dengan stabilitas lingkungan dalam teori SPACE. Ia merupakan dimensi eksternal dari HSO.

\section{Aspek Lingkungan bagi Organisasi}

Sebagai sebuah konstruksi sosial, organisasi terbentuk karena penyatuan visi dan misi, serta tujuan yang sama sebagai perwujudan eksistensi sekelompok orang terhadap masyarakat. Walau begitu, eksistensi organisasi tertanam dalam dan 
merupakan bagian dari masyarakat yang kompleks, memiliki sejarah yang unik dan terus saling terkait dengan individu, kelompok dan organisasi lainnya (Jones dan May, 1992:109). Aspek-aspek seperti kesejarahan, karakter organisasi, struktur organisasi, program organisasi, sumber daya manusia, stakeholders, policy making, dan aspek pendanaan (funding) berkembang seiring berjalannya organisasi (Austin, 2002: 78) dan memunculkan penekanan inti yang tidak lagi memaksimalkan, tetapi memuaskan.

Studi Burns and Stalker (1961) tentang The Management of Innovation memberikan pandangan bahwa organisasi yang efektif akan menyesuaikan strukturnya dengan kondisi lingkungan. Jones and May (1992) juga menjelaskan bahwa lingkungan dapat dipahami sebagai segala sesuatu di luar organisasi yang dapat mempengaruhi operasionalisasi organisasi atau bahkan organisasi tersebut justru dapat mempengaruhi lingkungan. Saling memberikan kontribusi pada keduanya (organisasi dan lingkungan) dapat memperkuat posisi organisasi di masyarakat. Lebih lanjut Robbin and Judge (2007) menegaskan bahwa lingkungan sebuah organisasi itu terbentuk dari lembaga-lembaga atau kekuatan-kekuatan di luar organisasi (eksternal) yang dapat mempengaruhi kualitas dan produktifitas kerja organisasi.

Kekuatan-kekuatan eksternal tersebut terkait dengan kebijakan-kebijakan pemerintah, kepentingan politik, persaingan antar organisasi, tekanan publik dan sejenisnya. Penegasan Robbin and Judge ini pernah dikemukakan oleh Tim Peneliti Tavistock Institute di Britania Raya pada 1951. Dalam penelitian tentang keterkaitan antara faktor teknik dan dimensi sosial di tempat kerja itu, kemudian dikembangkan pemahaman bahwa sebagai suatu sistem, organisasi harus merespon tekanan sosial, ekonomi dan teknologi. Hal ini berarti bahwa responsifitas organisasi terhadap dinamika lingkungan adalah bagian yang tidak bisa dihidari oleh organisasi. Karena itu karakteristik individu dan kelompok, persyaratan tugas dan interrelasi di antara mereka harus ditata dengan tepat dalam desain organisasi.

Kettner (2002) menjelaskan tentang pentingnya lingkungan bagi organisasi. Ada dua pengertian lingkungan, yakni lingkungan internal organisasi dan lingkungan eksternal organisasi. Mengutip pendapat Miles (1975) dalam Kettner (2002) bahwa lingkungan internal dari organisasi itu mempengaruhi kesuksesan organisasi karena mampu mengintegrasikan dua variable di dalamnya, yakni variabel manusia dan variabel struktur. Variabel manusia meliputi kemampuan, sikap, nilai- 
nilai, kebutuhan dan karakteristik demografis. Sedangkan variebel organisasi terkait dengan tujuan, teknologi dan struktur.

Montana and Charnov (1993) dalam Kettner yang menyebutkan bahwa terdapat lima faktor dalam memahami lingkungan internal organisasi, yakni terkait dengan; sumber keuangan, sumber fisik, sumber daya manusia, teknologi dan budaya/ethic. Akan tetapi kemudian Netting, Kettner and McMurtry (1998) dalam Kettner (2002:71) menyatukan sejumlah sumber dan penerapan yang lebih spesifik dalam Organisasi Pelayanan Manusia (OPM) yakni; 1) corporate authority and mission (otoritas dan misi lembaga/organisasi), 2) leadership style (gaya kepemimpinan), 3) organizational and program structur (struktur dan program keorganisasian), 4) programs and services (program-program dan pelayanan), 5) personnel policies (personalia kebijakan) dan, 6) technical resources (sumber daya teknis).

Sedangkan lingkungan eksternal organisasi itu menurut Kettner merupakan segala sesuatu yang berada di luar batas-batas dari instansi atau organisasi itu sendiri. Martin (1980) dalam Kettner (2002:66) menuliskan secara spesifik tentang Human Service Organization, mengidentifikasi sejumlah elemen-elemen eksternal yang meliputi; 1) funding sources (sumber pendanaan), 2) sources of noncash revenues (sumber pendapatan tidak langsung), 3) clients and client sources (sumber klien/nasabah), 4) other constituents (unsur pokok yang lain).

\section{Organisasi Berbasis Keagamaan/keyakinan (Faith Base Organization/FBO)}

Pemikiran Emile Durkheim bahwa memahami fenomena keagamaan bukanlah sekedar doktrin-doktrin tentang masalah-masalah supernatural, agama bukan pula sekedar ajaran yang terdapat pada manuskrip, melainkan sebuah gejala sosial yang merefleksikan kohesivitas dan solidaritas sosial masyarakat. Konsepkonsep moralitas dibangun sebagai sebuah kesadaran kolektif dan sebagai bentuk 'disiplin sosial' yang mengikat sebuah kelompok masyarakat secara kolektif. Dalam konteks ini, sebuah kehidupan etis atau mungkin 'religious', sangat tergantung pada kohesi dan solidaritas antara individu (Latief, 2013; 175). Dalam konteks organisasi, pemikiran ini dapat dipahami bahwa bergesernya penguatan arah orientasi organisasi yang didasari nilai-nilai ajaran agama, diperlukan adanya dukungan sosial dan untuk 
kepentingan kolektif. Dari konteks pemikiran inilah kemudian berkembang pemikiran tentang peran organisasi kegamaan dalam pelayanan kemanusiaan.

Kepedulian organisasi berbasis keagamaan pada isu kemanusiaan dapat dijelaskan secara sosiologis ataupun historis. Secara sosiologis, perspektif Individuo Globalisme sebagaimana Raphael Liogier, memandang kalau ada tiga kekuatan yang saling mendukung dalam FBO. yaitu kekuatan kultus spiritual, pertumbuhan pribadi (le narcissisme eclate), dan kepedulian pada keseluruhan alam semesta. Tiga kekuatan ini bermain dalam diri individu-individu yang terlibat dalam organisasi berbasis keyakinan (Benthall, 2008:94). Ini yang membedakan organisasi berbasis keyakinan modern dengan lembaga misionaris yang hanya bertumpu pada kekuatan kultus spiritual. Selain itu, organisasi berbasis keyakinan dapat dibedakan dengan organisasi berbasis sekuler dengan promosi yang dibawakan. Organisasi berbasis sekuler mendorong konsumen untuk membangun modal, sementara organisasi berbasis keyakinan mendorong konsumen untuk membangun kesejahteraan seketika lewat keyakinan.

Perspektif Durasi Panjang dari Terje Tvedt (Benthall, 2008:95), menempatkan faktor sintesis sebagai pendorong munculnya organisasi berbasis keyakinan. Dasar dari organisasi berbasis keyakinan adalah agama dan agama telah berusia ribuan tahun. Sementara itu, organisasi kemanusiaan sekuler baru lahir setelah Perang Dunia II. Menghadapi persaingan dengan organisasi kemanusiaan sekuler, agama memunculkan organisasi kemanusiaan religius. Tujuannya sebenarnya sama, yaitu memperoleh penerimaan dan modal (Benthall, 2008:95). Jadi, dapat dikatakan kalau motivasi di balik organisasi berbasis keyakinan hanya satu, yaitu menyebarkan agamanya.

Kedua perspektif di atas membenarkan kalau motivasi dari organisasi berbasis keyakinan adalah ajaran agama, dengan porsi yang berbeda. Kedua perspektif ini juga menunjukkan kalau ada permainan antara agama dengan sekulerisme, satu memandang kalau agama dan sekulerisme bekerjasama, sementara satunya lagi memandang kalau keduanya bersaing.

Dalam perspektif Liogier, pemikiran sekuler masuk ke dalam pranata agama dan mendorong lembaga agama membuat organisasi berbasis keyakinan, begitu juga sebaliknya, pemikiran agama masuk dalam lembaga sekuler. Hasil dari 
saling campur ini membuat gejala dimana pada praktiknya, tidak dapat dibedakan antara organisasi berbasis keyakinan dengan organisasi berbasis sekuler.

Pada perspketif Tvedt, agama bersaing dengan sekulerisme, dan agama merasa minor, terutama karena kemajuan ilmu pengetahuan dan teknologi di masa modern. Untuk tetap bertahan, agama harus mengadopsi sejumlah praktik sekuler namun pada intinya tetap pada ajaran agama. Hal ini tidak terjadi pada organisasi berbasis sekuler yang merasa percaya diri tanpa adanya komponen agama. Kalaupun organisasi berbasis sekuler memasukkan komponen agama, mereka akan menggunakan prinsip pluralisme, sehingga keyakinan diserahkan pada masyarakat tempat lembaga beroperasi. Jika lembaga beroperasi pada lingkungan mayoritas Islam, lembaga sekuler akan mengambil kandungan-kandungan Islam, begitu juga jika kasusnya pada agama lainnya. Lembaga berbasis keyakinan tidak adaptif. Mereka langsung menekankan satu keyakinan atas keyakinan yang lain dan mengutamakan bantuan pada orang dengan keyakinan yang sama dan jika berbeda, maka bantuan dimaksudkan untuk menarik orang tersebut ke dalam agama yang dijadikan dasar organisasi tersebut.

\section{Konsep Pelayanan Sosial dalam Faith Base Organization (FBO)}

Motivasi dasar dari FBO adalah ajaran agama yang diyakini. FBO sering menekankan kalau agama yang mereka usung merupakan jalan untuk memecahkan masalah sosial yang dihadapi. Pelayanan sosial yang diberikan FBO dapat bersifat kas ataupun modal sosial. Dalam pelayanan bersifat kas, akan lebih baik jika FBO bekerjasama dengan pemerintah sehingga tidak muncul kecurigaan kalau FBO berusaha merekruit pemeluk agama dari masyarakat yang menderita dengan semata menawarkan bantuan ekonomi atau makanan. Dalam konteks modal sosial, FBO dipandang lebih baik bekerja tanpa campur tangan pemerintah khususnya dalam melayani masyarakat miskin, minoritas atau mantan narapidana (Cole, 2002:571). Hal ini karena ketiga golongan tersebut telah memiliki ketidakpercayaan pada pemerintah dan lebih menyenangi sisi independen dari FBO yang langsung menghubungkan mereka dengan otoritas tertinggi yaitu Tuhan. Dalam beberapa penelitian telah ditemukan kalau pasokan dana dari pemerintah pada FBO memberikan dampak 
bergesernya orientasi FBO dari orientasi agama menjadi lebih sekuler dan meningkatkan beban kerja dan birokrasi FBO (Reese dan Shields, 1999:171).

Masalah ketika FBO terlepas dari pemerintah kemudian adalah niat oportunistik sekular, khususnya pemilik modal besar yang bergerak dalam ekonomi. FBO yang tidak memperoleh dana dari pemerintah dapat memperoleh dana dari swasta tunggal. Yayasan tertentu misalnya, dapat dengan sengaja membuat FBO untuk memperbaiki citra buruk perusahaan atau mempromosikan perusahaan agar memperoleh kepercayaan publik, walaupun pada gilirannya melakukan tindakan yang melanggar prinsip sosial kemanusiaan pada level atas seperti penyuapan atau pengurangan pajak (Cole, 2002:576). Bahkan ketika sumber dana tidak dapat diperoleh dari pemerintah atau lembaga swasta tunggal, FBO masih rentan dengan penyelewengan tujuan dengan lebih menekankan pada pengumpulan dan penumpukan sumbangan ketimbang pemanfaatan sumbangan yang ada untuk peningkatan modal sosial masyarakat yang dilayani (Cohen, 2001). Hal ini pada gilirannya memberi masalah dana bagi FBO untuk beroperasi dengan efektif dan efisien dalam memberikan pelayanan sosial berbasis keagamaan. Pada gilirannya, secara umum FBO beroperasi dengan sumber dana dari yayasan keagamaan atau sumbangan khusus (Reese dan Shields, 1999:191).

Walaupun terdapat permasalahan dalam sumber dana, FBO telah memberikan banyak kontribusi dalam pelayanan sosial. Di AS, FBO telah terlibat pada penyediaan dukungan bagi masyarakat miskin, misalnya; program pemulihan kecanduan narkoba, pengembangan perumahan, pelatihan kerja dan wirausaha, inkubator bisnis, dukungan konseling, dan penyedia kredit lunak (Reese dan Shields, 1999:170). Salah satu bidang pelayanan sosial yang paling efektif untuk dijalankan oleh FBO adalah pemulihan kecanduan narkoba. Korban narkoba, baik dari kelompok ateis atau teis, lebih mudah disembuhkan ketika agama digunakan dalam upaya pemulihan (de Jong dan Horn, 2008:147).

\section{Kesimpulan}

Strategi penguatan organisasi pelayanan sosial, sebaiknya tidak saja dilihat dari dimensi internal (spirit berorganisasi) namun juga memperhatikan dinamika ekternal (tuntutan kualitas pelayanan). Kekuatan organisasi selain dapat dilihat dari 
peran dan komitmen aktor, sebenarnya juga dapat dilihat dari bagaimana respon obyek organisasi terhadap misi organisasi. Sebagai bentukan sosial (komunitas keagamaan), sebenarnya organisasi pelayanan sosial yang berbasis keagamaan (FBO) semacam ini bukanlah organisasi yang anti pada perubahan.

Jika diperbandingkan Tesis Weber tentang rasionalisasi yang menunjukkan bahwa semakin menguatnya organisasi atau lembaga formal di masyarakat, justru akan mempersempit ruang-ruang keagamaan yang ada dan akan semakin menguatkkan gejala sekulerisasi, tidaklah terlalu benar. Dalam ajaran Islam, sebenarnya profesionalitas telah diajarkan. Artinya jika ruang keagamaan dipahami sebagai tidakan yang meminimalisir insentif (materi) maka dalam Islam justru profesionalitas sangat diutamakan. Merujuk pada Sabdah Rosullullah Muhammad SAW yang artinya; berikanlah pekerja upahnya sebelum keringatnya kering (HR. Ibnu Majah) mengindikasikan bahwa dalam Islam sangat berpihak pada pengutamaan pemberian insentif pada pekerja (yang ditugaskan).

Organisasi pelayanan sosial yang berbasis keagamaan (Islam) sebaiknya menerapkan nilai-nilai profesionalitas sebagai implementasi dari ajaran Rosulallah Muhammad SAW. Aktifitas berorganisasi tidak lagi menerapkan spirit emosional tetapi atas pertimbangan rasional. Rasionalisasi pengelolaan organisasi pelayanan sosial yang berbasis keagamaan menjadi salah satu strategi yang dapat dikembangkan untuk meningkatkan kualitas managerial dan kualitas pelayan yang ditawarkan.

Di Indonesia sebagai negara kolektivistik, tradisi saling membantu dan saling menyumbang telah banyak dilakukan masyarakat dan menjadi budaya luhur. Akan tetapi budaya ini tidak didukung dengan pola managerial yang proposional sehingga tidak berdampak bagi masyarakat padahal keberadaan FBO telah memiliki sejarah panjang dalam memberikan pelayanan sosial di Indonesia.

\section{Daftar Pustaka}

\section{Buku}

Austin, M. David. (2002). Human Service Management: organizational leadership in social work practice. Colombia University Press.

Benthall, Benthall, J. (2008). Returning to Religion: Why a Secular Age is Haunted by Faith. London: IB Tauris. 
Berger, P. L., \& Luckmann, T. (1966). The social construction of reality. Harmondsworth: Penguin.

Burn \& Stalker. (1994). The Management of Innovation. Oxford University Press. USA.

Holt, R., Sandberg, J. (2011). Phenomenology And Organization Theory. Dalam Philosophy and Organization Theory. Page 228. Editors: Haridimos Tsoukas dan Robert Chia. London: Emerald.

Jones, Andrew and John May. (1992). Workinh in Human Services Organisations. A ciritcal Introduction. Longman. Australia Page 84.

Kettner M. Peter. (2002). Acheiving Excellence in The Management of Human Service Organizations. A Person Education Company. Boston.

Lemert, Charles (ed). (1999). Social Theory the Multicultural and Classic Reading. Westview Press. Page 285.

Robbins, Stephen P. \& Timoty A. Judge. (2007). Organisational Behavior. Edisi 12. Diterjemahkan oleh Diana Angelica, Ria Cahyani dan Abdul Rosyid. Salemba Empat. Jakarta.

\section{Publikasi Ilmiah}

Barley, S. R. \& P. S. Tolbert. (1997). Institutionalization and structuration. Studying the links between action and institution. Organization Studies, 18(1), 93-117.

Latief, Hilman. (2013). Agama dan Pelayanan Sosial: Intepretasi dan Aksi Fiantropi dalam Tradisi Muslim dan Kristen di Indonesial. Religi. Vol. IX. No 2.

Meyer, J. W., \& Rowan, B. R. (1977). Institutionalized organizations. Formal structure as myths and ceremony. American Journal of Sociology, 83(2), 340-363.

Moravcsik, A. (1997). Taking Preferences Seriously: A Liberal Theory of International Politics, International Organization 51(4), 513-553.

Muslich, M. (2008). Kekuasaan Media Massa Mengonstruksi Realitas. Babasa Dan Seni, Tahun 36, Nomor 2.

Tienhaara, K.S. (2008). The Expropriation of Environmental Governance Protecting Foreign Investors at the Expense of Public Policy. Dissertation. Vrije Universiteit Page 83.

Zucker, L. G. (1977). The role of institutionalization in cultural persistence. American Sociological Review, 42, 726-743. 